\title{
KRESEK MAN IN ACTION: MOTIVE OF ENVIRONMENT CARE ACTION ON CELEBRATION OF THE BLITAR DJADOEL
}

\author{
Dadang Fredianto \\ Master of Social Science Program, University of Brawijaya \\ e-mail: fredianto.dadang@gmail.com
}

\begin{abstract}
Blitar Djadoel Celebration always successful every year. But the success is inseparable from the classic problems that accompany it. In 2019, the trash phenomenon at Blitar Djadoel became viral on social media because of the bad behavior of visitors. Unexpectedly, the phenomenon was increasingly viral due to the action of Kresek. Man who picked up trash in the Blitar Djadeol area. This study aims to determine the motive for the action of Kresek. Man with the Motive Concept (because motive and in order to motive) introduced by Alfred Schut:. This qualitative research with a phenomenological approach takes data through observation techniques, in-depth interviews, observations on social media and documentation. This study found that there was a motive for Kresek. Man actions that were seen in general and specifically. The action motives in general can be known through the reason Kresek. Man performs the action as a whole. While special motives can be known through the reason of Kresek. Man in selecting super hero costumes and figures, reasons for hiding identities, reasons for documenting the actions and reasons for making trash monuments. This research reveals that in each of these motives there are not always two types of motives, "because" and "in order to". In general, Kresek Man carried out the action caused by the trash phenomenon in Blitar Djadoel which was viral on social media. The action brings hope to educate the public about the importance of disposing of trash in its place.
\end{abstract}

Keyword: Action, Blitar Djadoel, Kresek Man, Motive, Trash.

\section{A. Backgroud}

Blitar Djadoel is an annual bazaar event organized by Blitar City Government in celebrating the city's anniversary. The celebration has been held since 2010 as a vehicle to preserve tradition and a place to promote regional potential. This year the Blitar Djadoel has been celebrated for the 9th time which was held from April 5 to 9, 2019 in Alun-Alun Blitar. A variety of local and old-themed products are sold at bazaar stands. Ranging from food to knick-knacks are presented from participants consisting of various groups, such as government institutions, schools, companies, and communities.

Like most bazaars, Blitar Djadoel invited many visitors, especially residents of Blitar Raya. They came and enjoyed the offerings prepared by the bazaar participants. There are those who buy a variety of foods, accessories and some are just a walk to enjoy the atmosphere of the past. The event was considered successful every year because it had a good impact on various sectors.

For example, the government sector, certainly gets appreciation from its citizens, so that they as government administrators always have good names. The private sector certainly gains economic returns from sales. 
School institutions also get valuable learning about entrepreneurship and skills. As well as the community, both as sellers and buyers also get profit and satisfaction. The symbiosis of mutualism claimed that the celebration of Blitar Djadoel every year should be thumbs up.

However, the heightened celebration of Blitar Djadoelwhich was assessed successfully seemed to bring environmental impacts that were very alarming. The excitement and euphoria of visitors unwittingly leave a polemic in the form of scattered trash. Those with a sense of innocence simply throw away the former food containers made of plastic such as plastic bag, plastic bottles and plastic glasses, straws, brochures and various other forms of trash.

That conditions worsened with the lack of trash bins provided by the committee so that visitors felt confused about where to dispose of the trash. Regarding this matter, the Head of the Tourism and Culture Office as the Head of the 113th Blitar City Anniversary committee said that in handling trash, the committee had cooperated with the Environmental Agency. That involves cleaners, cleaning trash every day after Blitar Djadoel closed. (http://blitarkota.go.id, 2019).

Based on the statement from the chairman of the committee above, it can be seen that efforts to overcome trash are not focused on providing adequate trash bins. But through the janitor who will clean up the trash when the Blitar Djadoel closed. That means what is done by the committee is a repressive effort, not a preventive effort by providing a lot of trash bins where visitors are expected to be able to dispose of their trash independently without relying on janitors.

The condition was increasingly viral with a post of photos of trash scattered in the Blitar Djadoel area by a netizen on the facebook account of Info Cegatan Blitar. A facebook group that contains all the information that happened in Blitar Raya. The post was then crowded with netizen's comments. In general, their comments are divided into two sides. On the first side, they blamed the committee for the lack of available trash bins. So that it is natural for visitors of Blitar Djadoel not to have a lot of choices, which ultimately dumps the trash in any place. The second side, netizens commented that even though there were not many trash bins provided, visitors of Blitar Djadoel remained in the wrong position. Whatever the reason, trash should not be thrown away carelessly. Visitors can store the trash first and then can dispose of the trash if they meet the trash bins.

The post was increasingly crowded with 320 comments and no less than 4,200 likers. The essence of the caption uploaded by the account named Dyah Ayu was to advise and insinuate citizens who like to litter. Citizens have been given interesting entertainment and free tickets. But all of that is not accompanied by good behavior in 
treating the environment. They littered and relied on janitors. At the end of the sentence, Dyah Ayu also invited visitors to be aware of cleanliness by removing trash in its place.

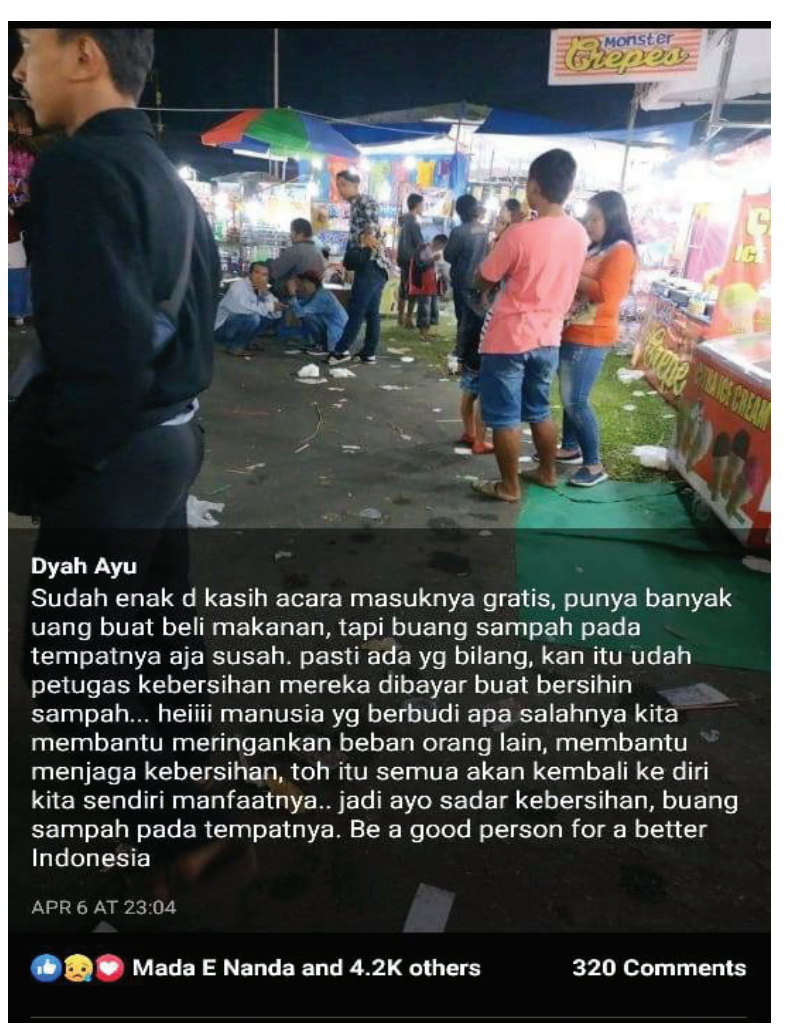

Picture 1. Dyah Ayu's Post

In addition to Dyah Ayu's post, many other netizens also talked about Blitar Djadoel's trash issues on their social media accounts. Conventional media also reported on the trash in the celebration, such as Radio Patria and Radio Mayangkara (Blitar local radio) and East Java Now. This proves that the trash in the Blitar Djadoel celebration has become its own polemic.

Shortly after the crowds related to the trash in Blitar Djadoel, right on the last day of the event, unexpectedly a superhero appeared wearing a costume from a plastic bag. He came with a mission to clean the environment that was not done by many others. Coming with some friends who acted as cameramen, he started his action by cleaning up the garbage in the Blitar area of Djadoel. With large plastic bags, scattered trash begins to be cleaned. Some visitors and sellers also took part in the action. Being the center of attention, it is known that the superhero figure is called Kresek Man.

Kresek Man was present in the middle of the trash problem that was in the Blitar Djadoel celebration. Many citizens are curious about the figure of Kresek Man. During this time, in Blitar Raya there was no figure who truly cared about the environment and took real action in public. Since the action, Kresek Man has become a public concern of Blitar Raya. Because in addition to the action, the publication of Kresek Man is getting more intense on social media, especially in the facebook group Info Cegatan Blitar.

The superhero figure reminds us of television series or films. Like Superman, Ultraman, Batman, The Avengers and so on. The essence of their mission is to eliminate all forms of crime and help the weak. The difference is that the actions on the glass screen are not real. While Kresek Man is a real manifestation of the superhero in eradicating environmental crime.

The Kresek Man figure that has been viral and unique brings its own charm to be explored more deeply. The background and purpose of the action are important points to know. Unique figures like Kresek Man are rarely found in Blitar, which in fact is a 
small city. Through this research, the Kresek Man action will be described in depth with Sociology analysis, especially with the Motif Concept introduced by Alfred Schutz. The concept is part of the Phenomenology Theory.

Social phenomenology introduced by Schutz presupposes three elements of knowledge that shape a human understanding of society, namely the everyday world, social actions and meanings (Sujatmiko et.al, 2014). Motives are one of the concepts that exist in the discussion of social actions. The social action introduced by Schutz is the result of criticism of the theory of Max Weber's Actions (Supraja, 2012). Through this concept, the Kresek Man action will be analyzed in depth with the research questions below.

\section{B. Research Questions}

What is the motive of the environmental care actions carried out by Kresek Man at the Blitar Djadoel Celebration?

\section{Research Purposes}

To find out the motive of the environmental care actions carried out by Kresek Man at the Blitar Djadoel Celebration.

\section{Practical Significance}

This research is expected to be able to serve as a reference for other researchers in a similar theme particularly the ones using subject theory from Alfred Schutz. For the community, the results of this study can transmit positive actions to care for the environment as done by Kresek Man. For the Government, the results of this study can be used as a reference to a new policy model and unique as exemplified by Kresek Man in managing trash and the environment.

\section{E. Research Methodology}

This research has been conducted since the issue of trash problems in the Blitar Djadoel Celebration, April 2019. With qualitative methods and phenomenological approaches, data was taken through observation techniques, in-depth interviews and observations on social media and documentation.

Observations were carried out directly in the Blitar Djadoel area, where it was seen in every corner of the bazaar that there was trash dumped carelessly. In-depth interviews were conducted directly with Kresek Man by looking at their experiences and actions as an inseparable entity. Kresek Man is the chosen subject. The selection of this subject uses a purposive sampling method in which Kresek Man really knows his action. Although in the end he objected if his true identity was displayed.

Meanwhile, observations on social media are still carried out to find out the dynamics of Kresek Man news by netizens in the form of narration and images. In this study, do not forget the documentation in the form of photos is also needed, which is obtained from the subject's personal 
documents as well as those circulating on social media.

The collected data is then analyzed using descriptive analysis consisting of data reduction, data display and conclusion. Data reduction is the process of selecting data in accordance with the focus of the discussion. Data that has been selected is then presented in the form of sub-discussion along with theoretical analysis. Then, conclusions can be drawn from the research.

\section{F. Concept Framework}

Alfred Schutz was an intellectual who was interested in Max Weber's thinking, but tried to clarify and develop it in the philosophy of Edmund Husserl's phenomenology which he knew personally. He developed phenomenology in sociology and as long as his academic career was devoted to improving sociological understanding of the world of life. He uses the source of phenomenology that Edmund Husserl developed to obtain a better understanding as the philosophical pillars of social science (Haryanto, 2012).

The phenomenology theory Alfred Schutz begins with the meaning of the action developed by Max Weber. Although the theory of action cannot be separated from Schutz's criticism. According to him, Weber's ideas which had been used as a reference for social thought were many unclear, vague, and inconsistent. However, with the blasphemy and criticism that Schutz raised on Weber's thinking in the end this figure succeeded in formulating a phenomenological perspective in sociology as the idea was expressed in one of his important works, The Phenomenology of the Social World (Supraja, 2012).

The social world according to Schutz must be seen historically. Therefore Schutz concludes that social action is an action that is oriented towards the behavior of other people in the past, present or future. In the context of phenomenology, the users are actors who carry out social actions with other actors, so that they have togetherness and similarities in the intersubjective meaning bonds. Following Schutz's thinking, users as actors may have one of two motives, namely future oriented motives (in order to motive) and motives oriented to the past (because motive) (Kuswarno, 2009).

"In-order-to" of an action or action is the orientation of the action against future events. But according to Alfred Schutz, before entering the "in-order-to" stage, first there is the "because" stage of each action, which has happened in the past (Kuswarno, 2009). Motive, pointing to the reason someone is doing something. In simple language, the motive in order-to is related to the reason someone does something as an effort to create situations and conditions that are expected in the future. Motive because it relates to a retrospective view of the factors that cause a person to take certain actions (Haryanto, 2012). 


\section{G. Discussion}

Kresek Man is a person who transforms into a superhero cares about the environment, who appears in the celebration of Blitar Djadoel. The man who is now 35 years old and living alone in a rented house on the outskirts of Blitar City, is a figure who loves the environment. His background as a member of the Pecinta Alam extracurricular when he studied at SMKN 1 Blitar, made him have more concern for nature and the environment.

Together with the Pecinta Alam organization, many activities were carried out. Not limited to exploring nature or climbing mountains like the current trend, Pecinta Alam at the time of their school also conducted clean environment activities, like cleaning dirty rivers in Blitar City. In addition to concrete actions, the doctrine of environmental sustainability is inherent in itself through theoretical material transmitted by the senior. He continued his love for nature after graduating from school until now.

Kresek Man considers that the current environment is a very serious problem. Waste from human activities has affected the ecosystem. At present, the weather is uncertain. Rain and heat cannot be predicted 20 years ago. According to him, the characteristics of the ecosystem that is starting to break down are that butterflies are rarely found. In the past, butterflies were often found anywhere, now it is very rare for butterflies to come even in artificial gardens.
Kresek Man's thinking about his love for the environment is not only transmitted through Pecinta Alam extracurricular. The factor of parents, especially mothers, greatly shapes him in looking of the world, including the environment. The habit of his mother who likes to talk about anything, makes Kresek Man always remember the values that can be taken. For example, his mother said, first everyone could live from the river near his house. People can bathe, wash clothes even for drinking water because of their clarity. Now, the benefits of the river cannot be felt because the flow is very small. All of that happened because of human activity.

"My mother likes to tell stories, anything. Environmental problems too. My mother said, the river behind the house used to be used a lot, for bathing, washing and so on. Now look, it can't be used because the flow is very small. All because human's doing". (Kresek Man, April 2019)

Kresek Man's love for the environment is proven by frequently participating in environmental care activities, such as routine community service, clean rivers along with cross communities, education to several schools and participating in various environment-themed seminars. All of them are done voluntarily. This volunteerism is what he thinks is the problem of environmental activists in Indonesia. The actions of 
environmental activists in Indonesia are limited due to economic problems. Different in developed countries, environmental conservation activities get a lot of funds, both from private and government.

In 2013, Kresek Man formed an organization called Indonesia Reborn for Independent (IRFI). Together with his friends as he thinks about the environment, he invites the community to rise independently to move to make changes in the environment. Initially, the routine activities carried out were river cleaning. However, due to a lack of clarity regarding the legality, the organization finally lost interest among its own members. So only Kresek Man and some of his friends still continue the environmental struggles until now.

The idea of Kresek Man was present when he saw a number of superhero figures in Japanese comics. He tried to criticize, that the superhero figure must appear in the real world and act with real actions. Because he is enthusiastic about the environment, why not that the superhero can be modified to look for actions that care for the environment. Crackle as the basic ingredient of the costume is chosen as a representation of waste that can damage the environment

The idea of Kresek Man appeared long before the celebration of Blitar Djadoel. Initially, Kresek Man was prepared for routine environmental activities, such as river cleaning. But only during the celebration of Blitar Djadoel, Kresek Man with his unique costumes dared to appear in public and viral on social media.

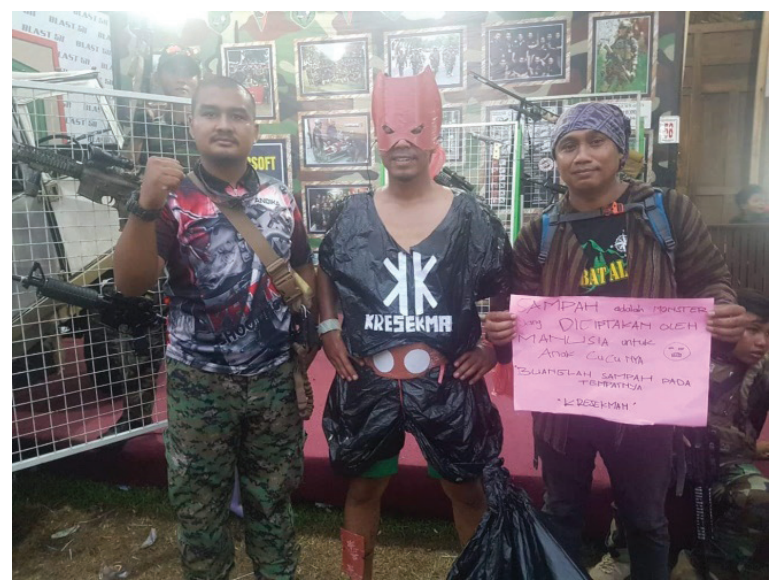

Picture 2. Figure of Kresek Man (Center)

The celebration of Blitar Djadoel, which left a problem with trash, made Kresek Man moved to take action. Right on the last day of the event, Kresek Man was present with some of the friends from other communities. With costumes made from crackle bags, he elaborated various sizes of crackers into a unique blend of clothing. Do not forget the superhero mask is also pinned on the head.

Right at 4 p.m., Kresek Man entered the Blitar Djadoel area. He started collected the trash, starting from plastic bags, plastic cups, brochures, and various other trash. A friend documented the action and another friend helped cellected the trash. Hundreds of visitors and bazaar participants were shocked. They look like a strange but unique figure. The action was the center of attention on that afternoon. 


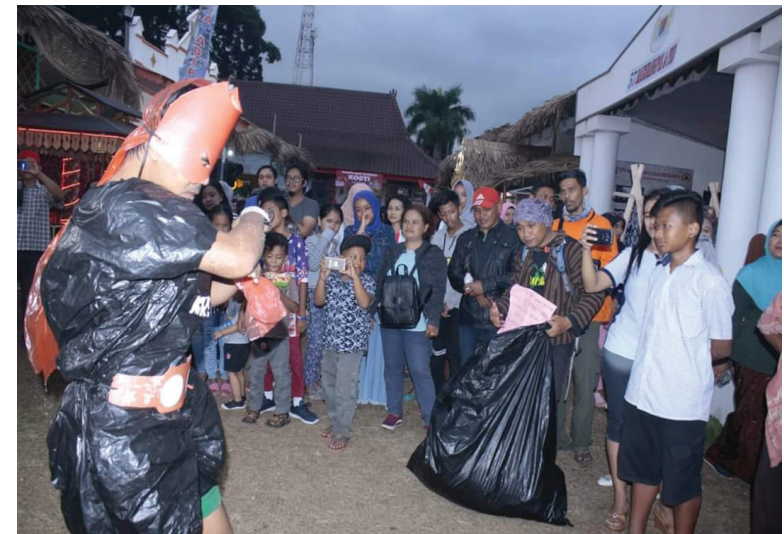

Picture 3. Kresek Man Action

Kresek Man action collecting trash unwittingly affects the people around him. At least, groups of school children and many people from both visitors and bazaar participants imitated and carried out the same actions with Kresek Man. Not only in one location, but Kresek Man also continues to move to another location and occasionally rests. The action was carried out for approximately 2 hours and ended at 6 p.m.

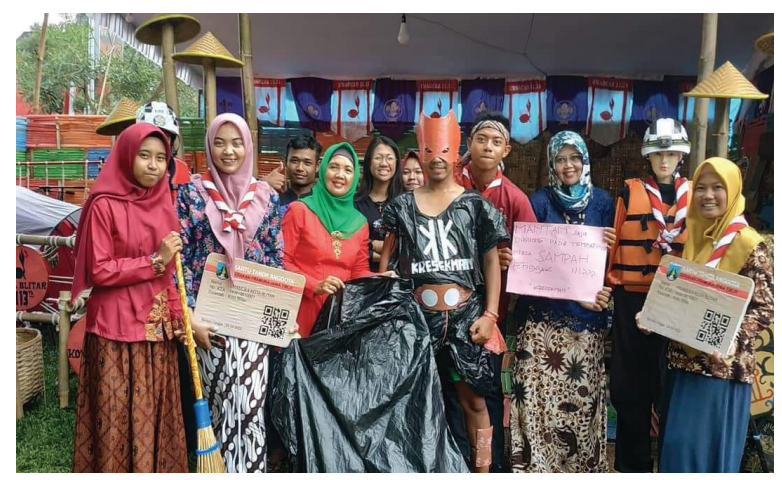

Picture 4. Some People Help Kresek Man

The collected trash is collected in large crackles and carried in an empty area near the exit of the bazaar. Kresek Man and his friends then took the initiative to make the trash into a monument, though not permanent. He called it a "Trash Monument", which is a symbol that the characteristics of our society do like trash. Not to forget, the monument was also written with critical sentences about environmental concerns. This is done so that people know that the trash that they produce is something that is very crucial and is a shared responsibility, not just the responsibility of the Environmental Agency.

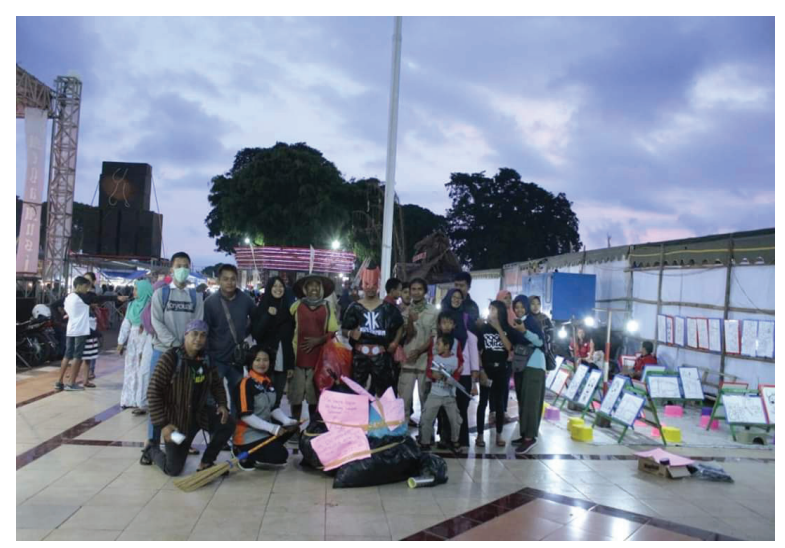

Picture 5. Trash Monument

After the action, the conversation about Kresek Man on social media was then viral. There are those who support the action, and many also consider that the action is only imagery and want to be famous. Regarding the accusation, Kresek Man turned out to have its own answer. The answer will be discussed in the next sub-chapter regarding the motives of Kresek Man to take action at the celebration of Blitar Djadoel.

The motive is the reason someone takes the action. This sub-chapter will discuss the motives of Kresek Man in carrying out their actions at the celebration of Blitar Djadoel. The concept of the Motive introduced by Alfred Schutz was used in this discussion as an analysis knife. If we reflect again, some actions of Kresek Man, in general, can be grouped into 3 stages. Namely the preparation stage, the execution stage and 
the completion stage. The initial stage, Kresek Man decided to choose the superhero figure that he designed in such a way with the basic material of crackle bag and he named it Kresek Man. At this stage, he also decided to hide his identity. His personal life tried to be separated from the figure of Kresek Man. The second stage is the execution stage where Kresek Man collects waste in the Blitar area of Djadoel. This stage also includes the reason for Kresek Man always documenting the action carried out by a friend. Where this action is considered by many people as just a form of imaging and wants to be known. The third stage, namely settlement. This stage, Kresek Man closes the action by making a monument from the collection of garbage, which is called the "Trash Monument".

The Kresek Man selection motive as a superhero who cares for the environment is motivated by several reasons. Both reasons that are "because" or motives that are "in order to". Kresek Man figure was constructed because the creator was inspired by a superhero from Japan. He really likes to collect Japanese comics with the theme of superheroes. Besides being very fond of the characters, in his reflection, he tried to criticize that superheroes should not only be limited to physical stories. But it can also be realized in real action.

The results of these reflections are truly realized in the form of Kresek Man. This motive is then in the Schutz perspective called "Because Motive". Action motives based on factors that cause an actor to decide on his actions. Kresek Man's knowledge and experience of superhero characters in comics formed his thoughts and decisions to construct the figure of Kresek Man.

In addition to the motives, the selection of Kresek Man is inseparable from the creator's goal to get hope in the future. According to him, the costume was chosen to get the attention of many people, especially children because of its uniqueness. It is hoped that Kresek Man will be remembered by many as a person who cares about the environment. So, it is expected that the community will always remember and imitate the action. The public will think again if they are going to dispose of trash because they remember the struggle of Kresek Man. This hope in the view of Alfred Schutz is called the "In order to Motive".

"I like that Japanese superhero, but I think it's better if the action can be real. well then I twisted, what if I made a Kresek Man, unique and really useful for the action, not just a fiction. If it's unique it can be remembered by people especially children" (Kresek Man, April 2019).

Behind his agile and passionate figure, it turns out that Kresek Man is a shy and introverted person. He admits that he does not believe in speaking or acting in public if he acts like himself. He actually was very brave to do the action behind the mask as Kresek Man. This background is one 
reason why he does not want the public to know about his personal life. In terms of the concept of Alfred Schutz's Motives, this reason is very representative of the concept of "Because Motive". Because the actor acts are influenced by the underlying reasons.

Apart from being shy, another reason for Kresek Man to hide his true identity is so that his personal life is not judged by others. Let others see the sincerity of the action of Kresek Man without seeing the background of his personal life. According to him, this is important to reduce speculation in the community. In Indonesia, the figure and background of someone who does something is still a very important thing to note. For example, this figure is a politician, businessman, or government official. Professional backgrounds like the one above will get a place in the hearts of the community because it is considered appropriate to do something. While ordinary people, the action is sometimes only considered as seeking material benefits. This was avoided by Kresek Man, so that the public saw him as the only superhero of the environment, regardless of the background of his life.

"Let people see Kresek Man who has a good mision. Don't see me. I am afraid that if my identity is known, people judge if a Kresek Man whose work is not clear, wants to do something strange. Because our society is still assessing, if it has to be someone who has a good position who can do something" (Kresek Man, April 2019).

The attitude taken by Kresek Man is quite successful. Apart from being consistent in not opening his costume, he also tried not to open up deep conversations while in the Blitar area of Djadoel. After the action was finished, he immediately rushed to go home. This motive has been confirmed planned from the start. The hope of Kresek Man for his personal secrecy, in Schutz's perspective, is clearly the In order to Motive. Kresek Man tries to create post-action conditions with very mature considerations before.

Kresek Man action collecting trash in the Blitar Djadoel area, at least motivated by two motives. These motives can be categorized into "Because Motive" and "In order to Motive". In terms of the Because Motives, it is clear that the selection action was a critical response to the trash phenomenon in the Blitar Djadoel. Moreover, this phenomenon has been viral and has become a conversation in the community. Kresek Man admitted that the posting of one of the netizens in the Info Cegatan Blitar group about the trash phenomenon had moved his heart to do something. At that time, according to him, the right moment to take action at the same time introducing a superhero figure that he had been concepting for a long time.

This factor conceptually included in the "Because Motive" category according to Alfred Schutz. However, the above factors 
are not the only reason why Kresek Man is carrying out the garbage collection action. A very important factor is related to the purpose of Kresek Man to carry out the action. According to his testimony, he took the action to educate the public, both adults and children, to dispose of trash in its place. The purpose of the action was very simple but was considered trivial by many people.

Education conducted by Kresek Man by giving examples to the community. He expects the community to be moved to throw trash in its place so that they feel embarrassed if littering. Children are also a concern for Kresek Man. He hopes action is a form of an effort to "cut generations", so children do not imitate littering behavior. He believes children will be more easily formed than adults.

Education is actually the main goal of Kresek Man to do the action. Many people assume that the action is merely an effort to save the environment. Or just keep the location of the Blitar Djadoel clean. But Kresek Man firmly replied that the main purpose of his action was to educate and make people aware that trash problems were a common problem. If it is associated with Alfred Schutz's concept, the purpose of this education is the "In order to Motive", because it is clear the Kresek Man projection of the action.

"If asked what the purpose is actually simple, only educating citizens, and especially children, that this trash should not be thrown away carelessly. We don't want to save the environment, because it's already late. We just want people to be aware". (Kresek Man, April 2019).

The motive for this trash collection action can also be raised as the main motive for the Kresek Man action, without discrediting the derivative motive which is also very important to know. Thus, the motives in general Kresek Man carry out the action against the background of the phenomenon of trash problems in Blitar Djadoel which is viral on social media. The action contains the intent and hope of educating the public about the importance of disposing of trash in its place.

Many people assume that the action of Kresek Man only seeks attention and wants to be known. Firmly, Kresek Man replied, yes. The documentation of the activities carried out by his friend was indeed uploaded on the facebook group Info Cegatan Blitar. In accordance with the "In order to Motive", this is done so that people know about the action. He admitted that he was doing imaging. According to him, imaging is important so that the figure of Kresek Man really becomes an icon of environmental care. If it is already known by the community, then the hope is that the community always remembers and is inspired by the action.

"If someone asks me if I want imaging, I admit I am indeed 
imaging. Because imaging has a positive side. With imaging people become aware, and know. So the hope is that people will always remember and be inspired by the crackle man” (Kresek Man, April 2019).

"In order to Motive" appear in the decision of Kresek Man made the Trash Monument. Making a non-permanent monument is a forward-looking projection of Kresek Man for an action. The Trash Monument is the hope of Kresek Man to the community to change their thinking about trash and the environment.

The Trash Monument made by Kresek Man and the participants is not without reason. The trash collected in several large crackle bags is lined up near the exit of BlitarDjadoel. The main reason why Kresek Man made this monument is to show the community that the trash is our responsibility. Not only one party's responsibility.

"This momumen so that people are aware, if this trash is a mirror of their behavior. If you already know, let's take responsibility. Because it's our shared responsibility, not just the responsibility of the government" (Kresek Man).

Because according to Kresek Man, no matter how good the government's efforts in managing trash, but if low public awareness will be in vain. Trash management must be carried out jointly, both government and society.

\section{H. Conclusion}

This study concluded that Kresek Man's motives for carrying out his actions at the celebration of Blitar Djadoel were not limited to caring and saving the environment. There are at least five categories of the Kresek Man action motive, starting from motives of the selection of The Kresek man figures, the motive of hiding identity, the motive of collecting trash, the motive of documenting the actions and motives of making trash monuments.

This study found that in every motive of Kresek Man there were not always two types of motives, "because" and "in order to". "Because Motive" arise when the decisions taken by Kresek Man relate to the experience and value of his life. While the motive "in order to" be more to a quick decision when he will do the action. However, the decision remains a projection of its action expectations.

The essence of some of these motives can actually be concluded in general motives. That the whole action of Kresek Man was motivated by the phenomenon of trash which was alarming at the celebration of Blitar Djadoel. As a critical response to the phenomenon, Kresek Man acted to educate and sensitize the public to dispose of trash in its place. Hope is very simple but very difficult for most people. 


\section{Reference List}

Haryanto, Sindung. 2012. Spektrum Teori Sosial dari Klasik hingga Postmodern Yogyakarta: Ar-Ruzz Media.

Kuswarno, Engkus. 2008. Metodologi Penelitian Komunikasi Fenomenologi Kensepsi, Pedomandan Contoh Penelitianya. Bandung: Widya Padjadjaran.

Sujatmiko dan Sugeng Haryanto, 2014. Studi Fenomenologi Perilaku Penumpang di Atas Gerbong Kereta Api. Jurnal Paradigma, Vol. 02 No. 01 : 35-39.
Supraja, Muhammad. 2012. Alfred Schutz: Rekonstruksi Teori Tindakan Max Weber. Jurnal Pemikiran Sosiologi Volume 1 No. 2, November 2012: 86-90.

Blitar City Government. 2019. Masyarakat Diarapkan Jaga Kebersiban Area Bazar Blitar Djadoel. https://www.blitarkota.go.id/id/ berita/masyarakat-di-harapkan-jagakebersihan-area-bazar-blitar-djadoel_ 